\title{
Bankers Acceptances and Unconventional Monetary Policy: FAQs
}

\author{
Richard G. Anderson, Vice President and Economist*
}

I n a previous Economic Synopses essay, I suggested that bankers' acceptances might assist the Federal Reserve in implementing its current "unconventional" monetary policy. Unconventional policy refers, here, to two actions: purchasing assets other than U.S. Treasury and agency securities or lending against collateral other than what is usually accepted at the discount window; and being concerned with the quantity of individual assets held, rather than only the total size of the Fed's monetary liabilities. Chairman Bernanke has referred to this policy as "credit easing." Such policy seeks to improve the functioning of credit markets, including short-term business finance (commercial paper), mortgage finance, home-improvement loans, student loans, small business loans, and others. Large volumes of such loans traditionally have been securitized; today, however, prospective purchasers of such loans are fearful, unable to develop usable measures of future credit risk.

\section{"Here, I answer selected questions asked by readers of my earlier essay."}

The assets purchased (and funds loaned) as part of unconventional policy, other things held constant, increase the Federal Reserve's liabilities dollar-for-dollar because the Federal Reserve pays for the assets with checks (or the electronic equivalent) drawn on itself. Since mid-September 2008, unconventional policy has caused extraordinary increases in the amount of deposits held by commercial banks at the Federal Reserve Banks. Federal Reserve policymakers argue that the increases are unimportant for the inflation outlook because they can be quickly reversed if and when conditions require (Bernanke, 2009). Among the public, however, the increases have raised concern because, historically, such rapid increases have been followed by higher inflation.

Some analysts and commentators have suggested that it would be desirable to invent a scheme wherein the Fed might provide increased credit market support while mini- mizing increases in the deposits held by banks at the Federal Reserve. The use of bankers' acceptances is such a scheme. Acceptances promise to restart these markets, drawing back into market finance the private capital that now seeks the safety of Treasury securities or federally insured bank deposits. At the same time, the Federal Reserve's balance sheet is relieved of the burden of providing the finance.

Here, I answer selected questions asked by readers of my earlier essay.

\section{Would a bankers' acceptance (BA) program at the Fed require any new/additional legislation?}

This issue requires more investigation. So far as I am aware, there are no provisions in the Federal Reserve Act that would prohibit such activity. In its early history, before the Great Depression, the Federal Reserve Banks purchased bankers' acceptances-that is, debts of private firms that had been "accepted" (guaranteed) by banks or acceptance corporations and were secured to the satisfaction of the Reserve Bank. My current proposal is quite different: A Reserve Bank (or a special purpose corporation chartered by a Reserve Bank) would accept the debt and then sell it to private investors. Section 14 of the Federal Reserve Act allows the Board of Governors to authorize "any institution" to accept debts that, if secured to the satisfaction of the Reserve Bank, are eligible for purchase by the Reserve Bank or acceptable as collateral for loans from the Reserve Bank ("discounted" by the Reserve Bank). Whether this applies to my proposal will require a ruling from Federal Reserve legal counsel. Historically, the Board has ruled that the accepting firm need not be a bank, but may be a nonbank institution that has traditionally engaged in the acceptance business. Also, the Board has ruled that the underlying loan contract need not be backed by physical commodities, so that the funds borrowed may be used by a firm in its ordinary course of business as working capital.

Important to the success of my proposal is that the acceptance be eligible for purchase or discount by a Reserve Bank, thereby ensuring payment at maturity. In ordinary 
times, eligibility is governed by a number of Federal Reserve regulations. In extraordinary times, these regulations are swept aside when section 13(3) of the Federal Reserve Act is invoked. Today, with section 13(3) in effect, the acceptance would have the same degree of risk as a U.S. Treasury security.

\section{Do we have any idea what the operating cost of a BA program at the Fed might be?}

Because this is a new idea, I have no cost estimate. I would expect the cost to be similar to other newly implemented Federal Reserve programs, including ones purchasing commercial paper and lending against asset-backed securities. An essential element is designing the acceptance contract and valuing the assets. How should the acceptance guarantee be priced? Should a fixed price be charged for the acceptance guarantee? Or a variable price that is adjusted based on performance of the underlying asset? These questions haven't yet been answered.

\section{What would be the ultimate cost, assuming widespread use?}

The cost of an acceptance plan likely is modest. Some defaults must be expected. Appropriate fees will defray, at least in part, the costs of defaults; perhaps they would also defray operating expenses. Yet, fees should not be so high as to discourage worthwhile participation since the purpose of the program is to restart credit markets during a time of heightened uncertainty. Setting high fees tends to disproportionately attract poorer-quality borrowers who have no alternative, while also discouraging better-quality borrowers that, despite quality, are shut out of financial markets because of heightened uncertainty. One option, perhaps, is to set a modestly high initial acceptance fee that is combined with an experience-linked rebate if actual defaults and losses are smaller than initially anticipated-rather like your auto insurance company sending a rebate. It must not be forgotten, however, that losses do occur when there is risk; taxpayers' money will be at risk. The public purpose in restarting credit markets must be balanced against possible losses.

\section{How quickly could a BA program begin? Would the financial crisis be over before the program starts?}

I suspect an acceptance program could be implemented relatively soon, especially if parts were outsourced to knowledgeable banking organizations. The Federal Reserve and private-sector financial institutions have considerable experience valuing collateral: Within the Federal Reserve, both the Discount Window and recently created special purpose vehicles are actively doing so. Further, the use of experience-based fees, as mentioned above, might speed implementation by easing the burden of precisely valuing heterogeneous assets.

5. Could a BA program be used to assist weak banking organizations, those holding large amounts of "toxic" or "legacy" assets that are reluctant to lend because of uncertainty whether they can obtain funds in the future?

It is important to be mindful that an acceptance program to support the Federal Reserve's unconventional policy is quite separate from the use of an acceptance program to resolve the banking crisis. The Treasury recently proposed a Financial Stability Program that includes forming a publicprivate partnership to acquire banks' legacy assets. When experience-based fees and contracts are used, the acceptance provides a flexible mechanism for distributing risk between private investors and public guarantors. To my knowledge, the Treasury has not considered acceptances.

6. Could the Federal Reserve achieve the benefits of a BA program in a more familiar manner by use of reverse repurchase agreements, that is, matched sale-purchases? In such transactions, the Federal Reserve sells an asset to a private investor with an attached agreement to buy back the asset at a specified future price on a specific date. Isn't this simpler?

One advantage of an acceptance is that the purchaser of the acceptance has a marketable financial instrument: the acceptance contract, which is payable on maturity to the holder. Typically, reverse repurchase agreements (RRPs) do not have such a feature-the commitment to repurchase the asset is with a specific investor. The investor in a RRP, essentially, has made a loan to the Federal Reserve-and the secondary market for loans may be thin. Also, it may be more difficult to write experience-based contracts for RRPs than for acceptances, that is, contracts that specifically address the default risk.

Anderson, Richard G. “Bankers Acceptances: Yesterday's Instrument to Re-Start Today's Credit Markets?" Federal Reserve Bank of St Louis Economic Synopses, 2009, Number 5.

Bernanke, Ben. "The Crisis and Policy Response." The Stamp Lecture at the London School of Economics, London, England, January 13, 2009.

${ }^{*} \mathrm{He}$ is also a visiting scholar at the School of Business, Aston University, Birmingham, U.K. 